\title{
The Development of Politics of National Defense Law in Safeguarding Indonesia's Sovereignty in the Era of Globalization
}

\author{
Sudarto $^{1 *}$, Abdul Rachmat Budiono ${ }^{2}$, Herman Suryokumuro $^{3}$, Setyo Widagdo ${ }^{4}$ \\ 1. Doctoral Candidate at Faculty of Law, Brawijaya University, Indonesia \\ 2. Lecturer at Faculty of Law, Brawijaya University, Indonesia \\ 3. Lecturer at Faculty of Law, Brawijaya University, Indonesia \\ 4. Lecturer at Faculty of Law, Brawijaya University, Indonesia
}

\begin{abstract}
The purpose of this study is to find out how the development of legal politics in the field of national defense since the reform era to the era of globalization. This type of research is normative legal research. This normative legal research is also known as doctrinal law research, using several theories, namely the political theory of law, the theory of popular sovereignty, the theory of authority, the theory of participation, the theory of national resilience. To sharpen the analysis, the writer uses the conceptual framework of the form of the state, the system of government and the concept of national defense. The results showed that the political law of the defense sector after the reform was placed on the concept of civil supremacy, which is based on the 1945 Constitution of the Republic of Indonesia NRI after the amendment pivots to the president as presidential power holder balanced with the role of parliament as a representation of people's sovereignty. President Joko Widodo has actively formulated a number of policies that are derived from the Defense Law, which became his duties and authorities by issuing a number of Government Regulations and Presidential Regulations related to various defense issues that began with Presidential Regulation 97/2015 on the general policy of national defense in 2015- 2019. The Presidential Regulation that has received sufficient public attention is Presidential Regulation 37 of 2019 concerning the functional position of the Indonesian National Army (TNI). This Perpres implements the provisions of article 31 of Government Regulation No. 39 of 2010 concerning the Administration of the Indonesian Armed Forces, which incidentally is the Government Regulation of the President Susilo Bambang Yudhoyono era. Thus in this case there is continuity of maintained political politics.
\end{abstract}

Keywords: legal politics, national defense, sovereignty, the Indonesian National Army (TNI).

DOI: $10.7176 / J L P G / 91-20$

Publication date: November 30th 2019

\section{A. Introduction}

National defense is in essence all universal defense efforts, the implementation of which is based on the awareness of the rights and obligations of all citizens and the belief in their own strength to maintain the survival of the nation and state of Indonesia which is independent and sovereign. ${ }^{1}$ The defense of the country, which is realized through active participation in the defense of the State, is an attitude, behavior, responsibility and honor that is imbued with awareness and love for the country. ${ }^{2}$

Legal politics is a part of the study of legal science which consists of two disciplines, namely political science and legal science. Moh. Mahfud MD, argues that legal politics is defined as a legal policy that will or has been implemented by the government. This legal politics includes the making of laws with the core of making and updating legal materials so that they can be adapted to the needs, and the implementation of existing legal provisions, including enforcement of the functions of institutions and fostering law enforcement. $^{3}$

The understanding of legal politics as proposed by Mahfud MD is in line with the understanding put forward by Abdul Hakim Garuda Nusantara which also means legal policy. ${ }^{4}$ The difference is that Abdul

\footnotetext{
1 Departemen Pertahanan Repubik Indonesia, Buku Putih Pertahanan Indonesia 2008, (Jakarta: Departemen Pertahanan RI, 2008), p. 43.

2 Pasal 27 ayat (1) UUD 1945 "segala warga negara bersamaan kedudukannya didalam hukum dan pemerintahan dan wajib menjunjung hukum pemerintahan

${ }^{3}$ M. Mahfud MD. Politik Hukum di Indonesia, (Jakarta: LP3ES, 1998), p. 8.

${ }^{4}$ Abdul Hakim Garuda Nusantara. Politik Hukum Indonesia (Jakarta: YLBHI, 1988), p. 27.
} 
Hakim prioritizes the study of legal politics in legal development, namely the need to include the role of social groups in society in terms of how the law is formed, conceptualized, implemented and institutionalized in a political process in accordance with the initial aspirations of a country. ${ }^{1}$

Padmo Wahjono holds that legal politics is the basic policy that determines the direction, form and content of the law to be formed. ${ }^{2}$ Whereas Soedarto explained that legal politics is a state policy through the state agencies that are authorized to set desired regulations that are expected and which are used to express what is contained in society and to achieve goals which become ideals. ${ }^{3}$ So the political law in this paper will focus more on how the basic policy of the Unitary Republic of Indonesia in achieving lasting sovereignty and peace as enshrined in the 1945 Constitution of the Republic of Indonesia.

Globalization is a process of international integration that occurs because of the exchange of world views, products, thoughts, and other aspects of culture. The emergence of transportation and telecommunications infrastructure including the emergence of telegraphs and the Internet, is a major factor in globalization which increasingly encourages interdependence of economic and cultural activities. ${ }^{4}$ Although some parties claim that globalization began in the modern era, several other experts trace the history of globalization to before the era of European discovery and voyages to the New World. There are also experts who noted the occurrence of globalization in the third millennium BC. ${ }^{5}$ At the end of the 19th century and the beginning of the 20th century, world economic and cultural connectivity took place very quickly.

The term globalization has been used more and more since the mid 1980s and more often since the mid 1990s. ${ }^{6}$ In 2000, the International Monetary Fund (IMF) identified four basic aspects of globalization: trade and transactions, movement of capital and investment, migration, migration of people, and liberation of knowledge. ${ }^{7}$ In addition, environmental challenges such as climate change, cross-border water and air pollution, and overfishing from the ocean also have to do with globalization. ${ }^{8}$ The process of globalization affects changes in business and work procedures, the economy, socio-cultural resources, and the natural environment. These changes cause different challenges in managing national defense. The essence is that politics, both the perpetrators and the institutionalization process, still faces a crisis of legitimacy, not only in the context of the relationship between the state and society, but also in the relationship between civilians and the military (civil military relations, CMR).

Until now the general policy of national defense has not been formally formulated. this is a strategic and political imperative that will guide the formulation of defense policy through the Department of Defense, and is a legal necessity as determined by Law No. 3 of 2002 concerning National Defense. In formulating the President's National Defense General Policy, he is assisted by a national security council in Law No. 3/2002 called the National Defense Council (DPN). ${ }^{9}$

In a crisis situation the existence of DPN is very necessary, especially when the government faces an emergency or urgent situation which must immediately be dealt with with all its risks, including when it must use instruments of violence and impose emergencies at various levels. As the President's hand, the political responsibility of the DPN rests with the President. The structure and membership of DPN outside permanent membership as stated in the law depends on the President in accordance with the interests and priorities of security issues within a certain period of time. To be operational, the national defense policy must be translated into some more concrete policies, which are also called defense policies, which are the responsibility of the Department of Defense, led by the Minister of Defense. ${ }^{10}$ The essence of defense policy is policy making and management.

The general policy of national defense shows that the Minister of Defense is not only authorized to formulate defense policies, but also controls the TNI, including control over the development of defense

\footnotetext{
${ }^{1}$ Ibid., p. 27.

2 Padmo Wahjono, dalam Mahfud MD. Politik Hukum di Indonesia. Jakarta: Rajawali, 2010), p.1. 6 Soedarto dalam Mahfud MD, Ibid.,p. 14.

${ }^{4}$ Al-Rodhan, R.F. Nayef and Gérard Stoudmann. Definitions of Globalization: A Comprehensive Overview and a Proposed Definition. (New york: Routledge, 2006), p. 14.

${ }^{5}$ Stever, H. Guyford. "Science, Systems, and Society" Journal of Cybernetics, 1972, 2(3), p.1-3.

${ }^{6}$ Frank, Andre Gunder. ReOrient: Global economy in the Asian age. (Berkeley: University of California Press, 1998).

7 "Globalization and Global History (p.127)"

8 International Monetary Fund. (2000). "Globalization: Threats or Opportunity." 12th April 2000: IMF Publications.

${ }^{9}$ Law No. 3/2002 concerning National Defense, Article 15.

${ }^{10}$ Ministry of Defense and Security of the Republic of Indonesia, Tingkatan kebijakan bidang pertahanan menurut Undang-Undang No. 3/2002 dalam Reformasi Sektor Keamanan Indonesia (Jakarta: ProPatria, 2004), p. $47-80$.
} 
forces whether they are in accordance with the power development policies formulated by the Ministry of Defense in accordance with general defense policies. The current condition of national defense is far from being able to support the domestic defense system. Institutional aspects and relations of authority are sensitive aspects because they contain political problems and power relations. Although legally regulated political and operational authority, this legal provision has not been implemented. Relations between the Department of Defense and National Police Headquarters are still overlapping. The position of commander directly under the President has political and psychological implications in his relationship with the Department of Defense.

Therefore in the future the government must reformulate the institutional-authority relations between political accountability and operational accountability so that democratic principles in the defense and security function can be realized. This is where the politics of law that harmonizes the spirit of democracy, sovereignty and legal certainty need to be built. The unification of political and operational responsibility is very easy to lead to various violations, including violations using the tools of violence. However, this does not mean that the TNI Commander and the National Police Chief do not have a channel to contribute their thoughts in the formulation of defense and security policies. A mechanism has been provided for this, namely through the national security council which in Law 3/2002 on National Defense is called the National Defense Council.

A national security council is tasked with analyzing issues of threats, where threats come from, and how to deal with these threats. The DPN provides advice to the President in making general policy on national defense, develops policies on the deployment of the defense component, and examines the risks of the policies set. But there are more fundamental functions. The chairman of the national security-council is also an advisor to the president in the field of security who communicates daily with the president. In a crisis situation, the existence of the Ministry of National Defense is very necessary, especially when the government faces an emergency or urgent situation which must be dealt with immediately with all its risks, including when it must use instruments of violence and impose emergencies. Based on this, it will be discussed about how the development of legal politics in the field of national defense since the reform era to the era of globalization.

\section{B. Research Method}

This type of research is normative juridical research which is a process to find the rule of law, legal principles and legal doctrines in order to address the legal issues encountered. ${ }^{1}$ The research approach used is the conceptual approach, historical approach and comparative approach. ${ }^{2}$ Legal materials used include primary legal materials consisting of legislation relating to this research, secondary legal materials which include, Minutes of MPR/DPR sessions relating to primary legal materials, Opinions of state constitutional law experts, particularly in the field of defense State, legal literature books relating to National Defense, Dissertations or Research Reports relating to National Defense, Articles and Papers relating to National Defense and Websites/Internet relating to National Defense, and Tertiary Legal Materials consisting of: Dictionary Law, Language Dictionary, Encyclopedia, Glossary and others.

The technique of collecting legal materials in this research was carried out through the study of laws and regulations related to an inventory based on the hierarchy of laws and regulations, through library studies by conducting literature reviews related to this research and through literature review, both manually and electronically via the internet. ${ }^{3}$ The analysis technique in this research is the content analysis technique, which is done by describing as it is for a condition or position of legal and non-legal propositions. ${ }^{4}$

\section{Results and Discussion}

\section{Thinking about Policies and Legislation in the Post-Reform Defense Sector}

It is a state's goal to make people happy and prosperous (bonum publicum/common wealth). In order to achieve these main objectives, the state has several other objectives, including: maintaining external security, meaning that the state protects its citizens against external threats; maintenance of internal

\footnotetext{
${ }^{1}$ Marzuki, Peter Mahmud. Penelitian Hukum (Jakarta: Kencana Prenada Media, 2011), p.35.

${ }^{2}$ Ibid, p. 138.

${ }^{3}$ Philipus M. Hadjon. Pengkajian Ilmu Hukum Dogmatik (Normatif), dalam "Yuridika” No. 6 Tahun IX Nopember-Desember Tahun 1994, (Surabaya: Airlangga University Faculty of Law, 1994), p. 6.

${ }^{4}$ Abdlatif and Hasbi Ali. Perihal Kaedah Hukum, (Bandung: Citra Aditya Bakti, 2010), p.9.
} 
security (maintenance of internal orders); and the achievement of prosperity which includes security, order, justice and freedom. ${ }^{1}$

But to meet these objectives, the state needs to be protected by preventing threats and attacks that come from outside or from within the country itself. Protecting the country is not only done by a legitimate state government, which has a mandate from the people to use all the nation's resources and potential, but also prepares an integrated national defense system that is integrated and involves all components of the nation. $^{2}$

Thus, there are several strategic aspects of national defense that need to be integrated and optimized for their existence and function within the framework of maintaining and defending the country, including aspects of the Military Organization, Military Industry, experts, facilities and infrastructure, components of citizens and state defense, Sources Natural Power (Food Security and Energy), Universe Defense System, Non-Military Defense System, Cold War (War of ideology).

\section{Transparency and Accountability Politics of the Defense Sector Budget}

During the 2019 Presidential Election, presidential candidate Prabowo Subianto criticized Jokowi for the fourth debate in the Presidential Election, Saturday (3/30/2019). He said Indonesia's defense budget was still too small compared to neighboring countries. Prabowo compared the defense and security budget to Singapore. "So Rp107 trillion is 5\% of our APBN, 0.8\% of our GDP, whereas Singapore has a defense budget of 30\% of the APBN, 3\% of their GDP," Prabowo said in the third segment of the presidential debate. Prabowo's remarks were in response against Jokowi's statement that the Ministry of Defense (Kemenhan) budget reached Rp107 trillion, the second largest budget after the Ministry of Public Works and Public Housing (PUPR).

In the defense ministry budget 2018 and 2019, it was Rp99.8 trillion and Rp108.4 trillion, respectively. Infographic Check Indonesia's Small Defense Budget Data When viewed in portions, the defense function is not a priority in the 2019 budget. Despite an increase from the previous year, this post only accounted for 6.63 percent of the total Central Government Expenditures of Rp1,634.3 Trillion. The function of defense consists of the procurement of military goods and services, the production of domestic industrial defense equipment and the development of the defense industry, the maintenance of personnel of army, marine and air force.

On the other hand, Jokowi's claim about the Ministry of Defense's second largest budget after the PERA Ministry of Public Works is indeed true. However, the Ministry of Defense budget allocated for Rp.108.4 Trillion (2019), slightly missed from the Rp107 Trillion figure submitted by Jokowi, could be that Jokowi refers to 2018 period data. Infographics Check Small Indonesian Defense Budget Data In 2018, the Ministry of Defense Budget is used for organizing national defense and national defense strategic plans. This strategic plan such as the personnel expenditure budget, building the Minimum Essential Force (MEF), improving the welfare of soldiers and civil servants of the Ministry of Defense and the TNI, coordinating and synchronizing the budget for non military defense with relevant Ministries and Institutions, and handling certain conditions that are emergency for humanitarian assistance. The Ministry of Defense budget allocation in the 2019 APBN in principle continues the 2018 budget, especially for improving the welfare of TNI members.

\section{The Role of the Military in Managing the Defense Sector}

During the 32 years that President Suharto was in power, the army even became the leader in the practical political stage so that it became the guardian of the state, not only during wartime, but also during peacetime. In a world atmosphere that has increasingly put forward civil supremacy today, the question is how should the restructuring and redefinition of the role of the military be carried out?

As the fall of the Suharto government and the beginning of the Reformation era, a movement so that the army was not on the political stage practically began. The disappearance of the ABRI Faction in the DPR was an important milestone. But then, what's the sequel? If what is desired is the upholding of civil supremacy, what will it look like? In civilian thinking, civil supremacy tends to be interpreted as civilian domination of the military. The reason is, if it is turned into military domination over civilians, it is against the democratic mindset. Even so, in terms of the military (especially since its heyday on the political stage of the New Order), civilian domination of the military is not a problem that can be taken for granted. Perhaps on the basis of experience that military domination of civilians tends to provide evidence that civilians are politicized by the military, in civilian domination of the military there are also concerns that the military will be politicized by civil.

${ }^{1}$ Syaiful Anwar, Melindungi Negara, (Jakarta: PustakaObor Indonesia, 2016), p. 3-14.

${ }^{2}$ See and compare with Syaiful Anwar, Ibid. 
As a solution to the problem of dominating and dominated above, now civilians and the military seem to be trying to reach a point of balance through compromise. The position of the Minister of Defense (Menhan) held by civilians and the position of the Commander of the TNI (military) which is equal to the Defense Minister is evidence of this compromise. In this pattern, there is no ordinate and no subordinates, no one rules and no one is governed. What exists is coordination between the civilian Defense Minister and the military commander in chief.

In this pattern civilian supremacy and military supremacy tend to be ruled out and the rule of law then emerges as a concept which is expected to replace it. Is the above really ideal? To this question, each person's judgment might be different. However, one thing that is clear is that if civil supremacy is deemed necessary, the emergence of strong civilian politicians with high personal integrity that will color the House of Representatives (and color the cabinet) is clearly needed..

Included in the above understanding is the emergence of political parties that are truly strong, professional, and well-established organizations as well as TNI organizations that continue to run well without relying on figures or those who lead them. In this connection, certainly it is also desirable if other civil organizations are able to grow into a strong forum and able to solve various problems. For example, preventing and resolving conflicts between civilians, whether conflicts are based on religious, ethnic or other issues.

If we assume that the instincts of guardian of the state have made the army hesitate to submit to civil supremacy, especially because civilians are not sure that they are capable of controlling the state, this impression of civil inability will certainly encourage and even justify the military's reluctance or doubt. . In the case of civil supremacy, it seems that only if civilians are truly prepared and capable, the role and power of the military on the political stage can be gradually reduced so that civil supremacy can finally be upheld. Efforts to strengthen the defense sector through the transformation of the modern defense system and the professional Indonesian national army through:

1.Building a modern state defense system and a professional TNI, underlining the importance of the defense budget, the adoption and innovation of defense equipment technology, the defense industry, and the welfare of soldiers;

2.Carrying out defense diplomacy that is in line with the building of defense forces to preserve the existing trust building measures (CBMs), as well as to prevent the security dilemma between Indonesia and the countries of the world;

3.Carry out defense budget reforms in accordance with the design of the development of defense forces;

4.Implement a defense equipment procurement mechanism that maintains a life cycle cost approach;

5.Continue the development of the defense industry towards independence in maintenance, production and innovation;

6.Improve the welfare of soldiers and their families through the provision of better basic salaries, health facilities, housing and a soldier's service program.

Presidential Regulation Number 97 Year 2015 concerning General Policy for National Defense Year 2015-2019. The National Policy on National Defense covers all efforts to develop, maintain, and develop in an integrated and directed manner all components of national defense. The 2015-2019 National Defense General Policy was made as a guideline for planning, organizing and supervising the national defense system. The main principles of the National Defense Policy include the National Defense Development Policy, the National Defense Empowerment Policy, the National Defense Force Mobilization Policy, the Regulatory Policy, the Budget Policy, and the Supervision Policy. ${ }^{1}$

According to Henry $\mathrm{Xu} \mathrm{Ke}$, Indonesia's maritime security capability has shortcomings in terms of Money (budget), Manpower (personnel), Machines (ships), and Methods (skills and training). It can be likened that sea power rests on the tools and technology used. In terms of money, Indonesia still has a weakness in the limited defense budget. ${ }^{2}$

In military expenditure issues, there is what is called the Minimum Essential Force (MEF) which is a term to describe projections and targets for the needs of a country's defense equipment and defense infrastructure. MEF, according to Purnomo Yusgiantoro, former Indonesian Minister of Defense 2009-2014, is an urgent need which if not fulfilled then the stakes are state sovereignty. This shows that on the one hand

${ }^{1}$ Regulation of the Minister of Defense of the Republic of Indonesia Number 19 of 2015 concerning the Implementation of National Defense Policy in 2015-2019.

${ }^{2}$ Henry Xu. The Indonesian New Maritim Security. Proposal Loaded On Maritime Monitor. 2007. p. 13-14. 
the fulfillment of people's welfare needs is important, but on the other hand there is also a need for security and defense which, if not fulfilled, will lead to greater threats to the sovereignty of a country. ${ }^{1}$

State as a focus in the study of International Relations. In line with the concept of security also refers to various interactions between actors that occur therein. ${ }^{2}$ According to Christian Reus-Smit: The state as a sovereign and independent political entity is a unit of analysis that is the focus of realism. ${ }^{3}$ The state in this case is an actor in international relations who is very rational in acting and determining the direction of his movement through a policy. This is because the state is responsible for the security of the country to create state security through the power of the country. So in a further security study in the book said in the security study there are 5 sectors that can occur in securitization. (1) Military, (2) Political, (3) Economic, (4) Society, (1) Environment. ${ }^{4}$

In creating a maritime defense posture Indonesia itself defines maritime security as: Increasing maritime security is done by deploying sea power capable of reaching outermost/outermost small islands, and effectively being able to maintain the sovereignty of the territorial sea territory of the national jurisdiction and directed to be able to monitor the security of the Pacific Ocean region. and the Indies. Increasing the security of the mainland, the country's land borders, and the outermost/outermost small islands is done through an effective land force title in territorial empowerment. ${ }^{5}$

Indonesia under the leadership of President Joko Widodo in building a defense posture will specifically focus on building maritime defense. This is in line with the President's policy regarding Indonesia as the World Maritime Axis, as explained in the background regarding maritime focus. Furthermore, in accordance with the Speech at the 2014 East Asian Summit, the President presented 5 (five) pillars of the PorosMaritim Development which included:

1. Building maritime culture;

2. Maintain and manage marine resources;

3. Infrastructure development and maritime connectivity;

4. Strengthen the diplomasimaritim;

5. As a country that is the fulcrum of two oceans, Indonesia is required to build maritime defense forces. ${ }^{6}$

In terms of the conception of the World Maritime Axis researchers will use geopolitical analysis and strategy as a step to find out the ideal "Axis" concept for Indonesia and its influence on the concept of maritime defense that will be formulated. According to Martin Jones, geopolitics are Rhys Jones and Michael Woods:

Political geography as a cluster of work within the social sciences that engages with the multiple intersections of 'politics' and 'geography', where these two terms are imagined as triangular configurations.

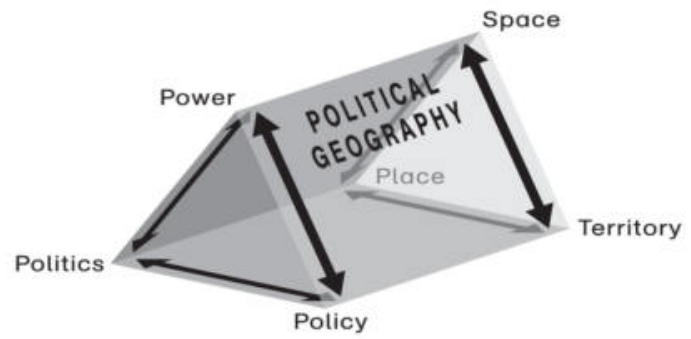

Figure 1. Political geography as an interaction of 'politics' and 'geography'

\footnotetext{
${ }^{1}$ Ihza, Yusron. Tragedi dan Strategi Pertahanan Nasional. (Jakarta: La Tofi Enterprise, 2009), p. 3.

${ }_{2}^{2}$ Alexsius Jemadu. Politik Global Dalam Teori Dan Praktik. (Yogyakarta: Graha Ilmu, 2008).p. 137.

${ }^{3}$ Christian Reus-Smit. Theories Of International Relations (3rd Edition). (New York:Palgrave Macmillan, 2005). p. 190.

${ }^{4}$ Ibid, p. 27

${ }^{5}$ Loc.Cit :"Buku Putih Pertahanan Indonesia 2015" p. 54

${ }^{6}$ Endah Murniningtyas. Optimalisasi Pemanfaatan Potensi Kelautan Menuju Terwujudnya Indonesia Sebagai Poros Maritim. (Jakarta:Bappenas,2016), p. 1.

${ }^{7}$ Martin Jones, Rhys Jones And Michael Woods. An Introduction To Political Geography Space, Place And Politics. (Newyork: Routledge, 2004),p. 2.
} 
The book further illustrates Geopolitics in a triangle configuration relationship between Power, Politics and Policy. ${ }^{l}$ The case study investigated by researchers is about strengthening the Navy's institutions. so that in relation to the construction of maritime defense postures, the TNI must be the front guard to create maritime security. The main task of the Navy is based on Law no. 34 of 2004 concerning the TNI, the navy has the following duties:

1. Carry out military duty matralaut in the field of defense.

2. Uphold the law and maintain security in the sea territory of national jurisdictions in accordance with the provisions of international law that have been ratified.

3. Carry out naval diplomacy in order to support foreign policy set by the government.

4. Carry out the tasks of the TNI in the development and development of autral force.

5. Carry out empowerment of marine defense areas.

To be able to create a maritime security, in establishing a maritime defense posture, Indonesia uses the concept of the Minimum Essential Force. The Indonesian government has released the concept of MEF development which is divided into 3 stages. According to the Ministry of Defense the minimum essential strength of the Minimum Essential Essential Force (Minimum Essential Force/MEF) is a standard of basic and minimum strength, which is part of the TNI's overall posture, and is absolutely necessary to be prepared as a primary and fundamental prerequisite for the effective implementation of its main tasks and functions TNI in facing the actual threat. ${ }^{2}$ The construction of the MEF of the TNI is expected to be able to realize a TNI posture capable of dealing with 2 (two) trouble-spots simultaneously, and 1 (one) reserve power to anticipate the emergence of additional threats.

From this framework, Indonesia's maritime defense development model that maritime defense that will be built by Indonesia must be a representation of Indonesia, including geopolitical and geostrategic realities, so that it can be concluded that maritime defense posture is a form of maritime defense that aims to create maritime security from various threat. In this case the researcher took focus on the role of the Navy's institution. to be able to carry out their duties optimally. RMA is a form of analysis of military institutions related to technology in this case related to alusista, the doctrine in this case is related to the reference in making a military strategy, management in this case is related to the internal structure of the Navy and its relationship with the governance structure. MEF is as a reference to create an effective defense posture related to resources needed by the Navy in creating maritime security.

In this study, researchers also used an intermestic approach that would bridge between domestic and international policies. Intermestic approach is a bridge between international and domestic approaches, so this model synthesizes several models, namely by using models that emphasize the role of transnational ideas as the first process and models that emphasize the interests of actors as the second process in the process of policy change. ${ }^{3}$

The assumption in this research is the embodiment of Indonesia as the World Maritime Axis in this case under the leadership of President Joko Widodo creating a marine security through the concept of defense posture using the MEF concept. As well as the role of the Navy that is less than optimal so that it needs a reformulation related to these institutions and this indicates that Indonesia as the World Maritime Axis has not run optimally. And also as a form of protection from traditional and non-traditional threats at sea.

\section{Conclusions}

The political law of the defense sector after the reformation is placed on the concept of civil supremacy, which is based on the 1945 Constitution of the Republic of Indonesia after the amendment pivots the president as the holder of presidential power which is balanced with the role of parliament as a representation of people's sovereignty. In this context a defense sector design was formulated as outlined in the statutory regulations in the form of a Defense law that both the president and the DPR were bound by statutory provisions. The DPR itself must have professional capabilities in carrying out these three functions so that the management of the defense sector can be carried out effectively and efficiently. However, the DPR still has limitations in balancing the role of the executive in managing the defense

${ }^{1}$ Ibid

${ }^{2}$ Op.Cip. Buku Putih Pertahanan Indonesia 2015

${ }^{3}$ Dyah Estu Kurniawati, Pendekatan Intermestik dalam proses perubahan kebijakan : Sebuah Review Metodologis. 
sector. Thus, President Joko Widodo has actively formulated a number of policies that are derived from the Defense Law which become his duties and authorities by issuing a number of Government Regulations and Presidential Regulations related to various defense sector issues beginning with Perpres 97/2015 concerning general defense policies of the year 2015-2019. A Presidential Regulation that is adequately gaining public attention is Presidential Regulation 37 of 2019 concerning functional TNI positions. This Perpres implements the provisions of article 31 of Government Regulation No. 39 of 2010 concerning the Administration of the Indonesian Armed Forces, which incidentally is the Government Regulation of the President Susilo Bambang Yudhoyono era. Thus in this case there is continuity of maintained political politics.

\section{Reference}

Abdul Hakim Garuda Nusantara. Politik Hukum Indonesia. (Jakarta: YLBHI, 1988).

Abdlatif and Hasbi Ali. Perihal Kaedah Hukum, (Bandung : Citra Aditya Bakti, 2010).

Alexsius Jemadu. Politik Global Dalam Teori Dan Praktik. (Yogyakarta: Graha Ilmu, 2008).

Al-Rodhan, R.F. Nayef and Gérard Stoudmann. Definitions of Globalization: A Comprehensive Overview and a Proposed Definition. (New york: Routledge, 2006).

Christian Reus-Smit. Theories Of International Relations (3rd Edition). (New York:Palgrave Macmillan, 2005).

Dyah Estu Kurniawati. Pendekatan Intermestik dalam proses perubahan kebijakan: Sebuah Review Metodologis.

Endah Murniningtyas. Optimalisasi Pemanfaatan Potensi Kelautan Menuju Terwujudnya Indonesia Sebagai Poros Maritim. (Jakarta:Bappenas, 2016).

Frank, Andre Gunder. ReOrient: Global economy in the Asian age. (Berkeley: University of California Press, 1998).

Henry Xu. The Indonesian New Maritim Security. Proposal Loaded On Maritime Monitor Maritime Monitor, 2007.

Ihza, Yusron. Tragedi dan Strategi Pertahanan Nasional. (Jakarta: La Tofi Enterprise, 2009).

International Monetary Fund. Globalization: Threats or Opportunity. (MF Publications, 2000).

Mahfud MD. Politik Hukum di Indonesia. ( Jakarta: LP3ES,1998).

Martin Jones, Rhys Jones And Michael Woods. An Introduction To Political Geography Space, Place And Politics. (Newyork: Routledge, 2004).

Marzuki, Peter Mahmud. Penelitian Hukum (Jakarta : Kencana Prenada Media, 2011).

Ministry of Defense of the Republic of Indonesia. Buku Putih Pertahanan Indonesia 2008. (Jakarta: Departemen Pertahanan RI, 2008).

Ministry of Defense and Security of the Republic of Indonesia, Tingkatan kebijakan bidang pertahanan menurut Undang-Undang No. 3/2002 dalam Reformasi Sektor Keamanan Indonesia (Jakarta: ProPatria, 2004).

Padmo Wahjono, in Mahfud MD. Politik Hukum di Indonesia. (Jakarta: Rajawali,2010).

Philipus M. Hadjon. Pengkajian Ilmu Hukum Dogmatik (Normatif), dalam "Yuridika" No. 6 Tahun IX Nopember-Desember Tahun 1994, (Surabaya: Airlangga University Faculty of Law, 1994).

Stever, H. Guyford. Science, Systems, and Society. Journal of Cybernetics, 1972, 2(3):1-3.

Syaiful Anwar. Melindungi Negara, (Jakarta: PustakaObor Indonesia, 2016).

\section{Laws And Regulations}

Republic of Indonesia, Article 27 paragraph (1) of the 1945 Constitution "all citizens are at the same position in law and government and must uphold government law.

Republic of Indonesia, Law No. 3/2002 concerning National Defense, Article 15.

Republic of Indonesia, Regulation of the Minister of Defense of the Republic of Indonesia Number 19 of 2015 concerning the Implementation of National Defense Policy in 2015-2019. 